\title{
PUBLIC MORALITY AND THE NEED FOR AN ETHOS OF HOSPITALITY
}

\author{
Robert Vosloo \\ Department of Systematic Theology and Ethics \\ Stellenbosch University
}

\begin{abstract}
This article sketches the prevailing sense of moral crisis with reference to the film Code Unknown. Following this cultural diagnosis, it analyses three responses to such a sense of moral crisis and suggests that an ethos of hospitality is necessary for the sake of public morality. It concludes by offering an analysis of five dimensions that may be identified with reference to such an ethos of hospitality.
\end{abstract}

\section{The moral crisis: Code unknown?}

Let me start be recalling a film that I saw a while ago and that in my view offers a powerful challenge to our thinking about morality and public life. This film, directed by Michael Haneke, is titled Code Inconnu (Code Unknown in English). It is subtitled Incomplete stories of several journeys. Haneke is also the director of the more recent film The Piano Teacher.

The film tells the story, or rather stories, of several lives that are only loosely connected. The setting is mostly a boulevard in Paris, but in our globalised age it can be any city London, Amsterdam or Cape Town. The film starts with Anne, played by Juliette Binoche, leaving her apartment building. Outside she finds Jean, the younger teenage brother of her boyfriend, George. He does not have the new entry code to her apartment and she gives it to him unwillingly after hearing that he has run away from his father's farm. Anne buys Jean something to eat from the bakery and when he walks back to the apartment he throws the empty paper bag into the lap of a begging middle-aged Romanian woman (Maria). A young Franco-African man, Amadou, challenges Jean, saying that he cannot act like this. He asks him to apologise to the woman and a scuffle ensues. The police arrive and Amadou, who has been the target of racism before, is arrested together with Maria. Amadou is later released but Maria, who is an illegal immigrant, is deported to Romania.

The rest of the movie is an intelligent narration of the four (incomplete) stories of the characters introduced: Anne and her boyfriend George; Jean and his father (the farmer); Amadou and his African family and Maria, the Romanian woman.

The camera follows Maria to Romania where we see her being reunited with her extended family. She confesses her feelings of shame and indignity because she had to beg - but they needed the money. They live in a house that is still being built. Maria later (towards the end of the movie) returns illegally to the street corner in Paris only to find that her place has been taken by another immigrant. She is harassed by shopkeepers and other minority groups. Her future does not look bright.

Amadou, the young Franco-African, teaches at a school for deaf-mute children. He has a deaf sister. We see how his father, a taxi-driver, struggles with dignity and honesty to keep the family together. It is, however, no easy matter.

Next to the stories of Amadou and Maria we have the story of Anne and her boyfriend George. George is a war-photographer returning from Kosovo. Later in the movie we see how he tries to capture the alienation of city life through his pictures. We see the troubled 
relationship between him and Anne and their difficulty in communicating their feelings. Anne is an actress that plays in a thriller-movie from which we see different scenes of her helplessly trapped in a sealed room, unable to escape from "the system." The powerlessness of the person trying to escape is depicted in a way reminiscent of a Franz Kafka novel. Throughout the movie we see how Anne and George communicate with the world either in front of the camera (Anne through the movies) or behind the camera (George), but not with each other.

Later in the movie Anne takes the Metro. A young Arab mocks her for being beautiful and privileged. He follows her in the Metro and spits in her face. A middle-aged Arab man challenges the youth and asks him to apologise. He refuses (just as Jean did not apologise to Maria). Anne is disturbed and she does not understand the young Arab's hatred and frustration.

Towards the end of the movie George arrives at Anne's apartment - to find that the code has been changed (probably to keep Jean out). It is raining and he tries to phone from the public phone, but the one phone is not working and he cannot gain access to the other phone. He walks away and it is as if he does not have the motivation to sustain the relationship any longer.

Another story line in the movie introduces George and Jean's father, who is a farmer. Jean and his brother do not want to farm. The tough economic times are well portrayed in a scene where the father offers Jean beetroot and bread as this is all there is to eat. They eat in silence. Later in sadness and frustration the father shoots his cows because the farm has no future prospects. The global economy, which he does not understand, influences his life in a direct way.

In the powerful opening scene of the movie we see a deaf-mute girl at school who tries to communicate her emotion. The other pupils try to guess her feeling and assume things like loneliness, sadness, confusion, imprisonment etc. The movie ends with a return to this scene in which a young child again tries to communicate something. This ambiguous scene seems to suggest something of the frustration due the difficulty of communication in an age in which the code is unknown, as well as the longing for real communication.

According to the director of this film (Michael Haneke) it is difficult to say what the film is about, but that in a way it deals with life in a multicultural situation. It depicts the isolation and fragmentation in a society marked by, among other things, the incapacity to communicate, a Babylonian confusion of languages, xenophobia, the disparity between rich and poor and the coldness of consumer society.

Behind all of this is the idea that the code is unknown. The code to open up the world and each other for love, friendship and hope seems to be lost. In such a world in which the code is unknown we must conduct our personal affairs and interact with strangers.

The film asks some serious questions through its cultural diagnosis about the problems of a society built on inequality - racial and economic. It shows the lack of communication (on an individual and social level - also inter-generational). There is a lack of willingness to communicate. We see hostility and isolation, and the lack of responsibility for the other.

\section{The moral crisis and possible responses}

The cultural diagnosis and questions asked in this film seem to be applicable to our moral crisis in South Africa. Certainly the context in South Africa is different to that of modern France, but the same experience that the code is unknown seems to prevail.

Often we hear the statement that people are more immoral today than in the past. Such a statement is problematic and is the result of a certain kind of amnesia with regard to 
history. It does seem evident, however, that we are experiencing a crisis in our moral vocabulary due to our changing cultural situations - hence our apparent inability to speak sufficiently and meaningfully about moral matters. For some yesterday's moral truths seem meaningless, while for others the new moral directions seem untrustworthy. There seems to be a total lack of moral consensus and discussions on moral matters are for most people a frustrating exercise.

Indeed, there seems to be no accessible moral code. The code is unknown. All that prevails is a Babylonian confusion of moral languages. Given the logic of the global market, we can ask the question whether our situation is really a situation of an "ethics after Babel" (to use the memorable title of a book by the moral philosopher Jeffrey Stout). ${ }^{1}$ Nonetheless the question still remains how to respond to the moral crisis partly depicted in Haneke's film and as experienced daily by millions of South Africans? There are certainly many possible responses, but let me highlight - by oversimplifying - three possible responses often reflected in our dialogue and actions with regard to the so-called moral crisis.

\section{Towards universal morality or common values?}

One possible response is to make a plea that we must search for common values that will unite our different moral worlds and thus enable peaceful co-existence. This plea usually owes much to Enlightenment-based ethical and political theories that seek some kind of universal morality by grounding morality in rationality and adhere strongly to the values of liberal democracy. This quest, however, has been severely criticised by those who maintain that such a universal morality is not as tradition- or narrative-free as often implied. A socalled 'universal' morality often serves the interests of specific people or groups and hence the suspicion about its universality. With regard to universal moral languages, the problem seems indeed to be that nobody speaks them. ${ }^{2}$

A further point of critique against the search for common values is that it overemphasises the importance of social arrangements, while neglecting the importance of the role of social agents. This is often the critique of those who adhere to some version of virtue ethics. Morality is not merely about common values, but about (uncommon) people who embody these values - people who are formed in communities through certain truthful narratives and role models.

Events like the September 11 tragedy in the United States and the responses it evoked and continues to evoke point to the importance of some kind of dialogue that unites rather than divides. The question can, however, still be asked whether the notion of common values is a sufficient notion for facing the challenges of globalisation and the concomitant upsurge in local identities.

\section{Flight from 'reality'?}

A second response to the moral crisis is that of some kind of flight from reality - often resulting in a type of inward emigration. Given the painful and despairing experiences of reality, it seems better to escape from "reality" through the many options available in consumer society.

Perhaps this is one of the reasons for the popularity of so-called 'reality television'. At the height of the controversy about the first series of the Big Brother programme somebody

1. Stout, J, Ethics After Babel (Boston: Beacon Press. 1988).

2. "The 'sad little joke' about universal languages, Mary Midgley once said, is that almost nobody speaks them" (Jeffrey Stout, Ethics After Babel, 166; quoted from Midgley, M, Beast and Man, 306). 
responded to the moral, and often moralistic, critique against the programme by saying in a passionate letter to the Afrikaans newspaper Die Burger something along the lines of: "To hell with you all. I am addicted to Big Brother. I watch it every moment I can, it is all I watch." She then quotes somebody who says she is part of a sick society. She responds by saying, "They are right - we have for a long time been part of such a sick society - a society that kills children, murders old people and where right is wrong and wrong is right. The violence is not going to stop - so I am going to watch Big Brother."

This is probably not the time to launch a discussion on the moral implications of reality television programmes - but it does seem interesting that these programmes are described as reality television. It seems better to watch so-called 'reality' (a reality where people mostly don't work or have children) than to live reality. ${ }^{3}$ Or maybe it is part of a critique against the definitions of "reality" offered by those with power in society.

The interest in reality television reflects something of the longing for the real, but also represents something of the flight from reality. It speaks for itself that the "flight from reality" response, while understandable, offers an inadequate moral response for dealing constructively and creatively with the challenges posed by our changing cultural situations.

\section{Back to community?}

A third response to the moral crisis is to bemoan the growing individualism and make a plea for a return to community. Such a communitarian approach is viewed by many as an alternative to secular liberalism. ${ }^{4}$ Certainly a critique against the isolating, modern, freefloating self is needed. But we also know that the plea for a return to community as an answer to the moral crisis is not unproblematic. Which community, we may ask, must we return to? Do we not live in different communities - communities with conflicting goals and values? Communities can be parochial, sectarian, stuffy and totalitarian. It is not just about choosing between the individual and community, but about finding creative and responsible ways of relating the individual and the community (or getting beyond the limitations of these juxtapositions).

\section{The need for an ethos of hospitality}

We can qualify and add to these responses, but let us proceed to a more constructive proposal. The challenge posed by the moral crisis does not merely ask for tolerance and peaceful co-existence or some abstract plea for community, but for an ethos of hospitality. The opposite of cruelty and hostility is not simply freedom from the cruel and hostile relationship, but hospitality. Without an ethos of hospitality it is difficult to envisage a way to challenge economic injustice, racism and xenophobia, lack of communication, the recognition of the rights of another, etc. Hospitality is a prerequisite for a more public life.

The notion of hospitality is inherent to the Jewish and Christian moral traditions. It is also a prominent virtue in other religious and moral traditions. It is not my aim in this paper to give a thorough discussion of hospitality within the biblical traditions, but it is clear that the notion of hospitality offers one of the important strands in Hebrew and Christian

3. It reminds of Jean Baudrillard's analysis of the early experiments with reality TV in the USA in his book Simulation and Simulacra (Ann Arbor: The University of Michigan Press, 1981), 1-41. Baudrillard develops the notion of hyperreality and writes for instance with reference to Disneyworld: "Disneyland exist in order to hide that it is the "real" country, all of "real" America that is Disneyland ... Disneyland is presented as imaginary in order to make us belief that the rest is real, whereas all of Los Angeles and the America that surrounds it are not longer real, but belong to the hyperreal order and the order of simulation" (12).

4. In this regard the work of Alasdair MacIntyre, Michael Sandel, Michael Walzer, Charles Taylor and Stanley Hauerwas is often mentioned. 
Scriptures. ${ }^{5}$ With regard to the theme of our conference, and the analysis offered at the beginning of this paper, let me proceed by making five short and searching remarks about the promise of an ethos of hospitality for public morality.

\section{Hospitality as challenge to enclosed identity}

One of the dangers to a more moral public life is the mindset of an enclosed identity. A mindset of enclosed identity aims at protecting my/our identity from what is different and other. While certain social and religious groups certainly must claim or reclaim their identity, it is important that the resources in these traditions that enable greater hospitality should be regained. While an ethos of hospitality, as openness to the other and to otherness challenges the mindset of enclosed and stuffy identity, it is not to be equated with a liberal, romantic openness towards otherness in which the other is viewed as an abstract ideal that serves to satisfy our aesthetic appetite for strangeness. Such a romanticised view fails to take the concrete identity of the other seriously and thus also insulates the self from the other and otherness.

An ethos of hospitality thus has the potential to challenge notions and practices of enclosed identity and romanticised otherness in a way that enables a more creative and responsible rethinking of the relationship between identity and otherness, or sameness and difference.

In the movie Code Unknown we see that there is not merely an inability to communicate, but also a certain hostility in the communication that does take place. We sense a certain fearful logic and the strategy of exclusion as a way of dealing with the other. Over against such a mindset hospitality is, to use the Croat theologian Miroslav Volf's term, about the will to embrace. It is about opening my/our identity to the other. The notion of the will to embrace is a way of expressing that "the will to give oneself to others and "welcome" them is prior to any judgement about others, except that of identifying them in their humanity." 6

I think that the language of hospitality as the will to embrace can enrich our public moral language by giving a richer account of co-existence than that which some of the "thinner" theories of justice provide. It points further than mere legal or contractual arrangements.

\section{Hospitality as temporal and spatial embodiment}

To (re)claim the importance of an ethos of hospitality for public morality is not merely to make a plea for hospitality as an abstract value that needs to be added to our moral codes or lists of core values. An adequate ethos of hospitality requires embodiment - embodiment in time and space. This, however, does not only provide the most important opportunities for an ethos of hospitality, but also raises the greatest difficulties.

Hospitality requires time, it requires embodiment in time. Given our global economic framework and acceleration culture, we can reply that time is the one thing we don't have. It is a matter of the survival of the fastest. Those who lack speed and mobility are marginalised. Hence we experience daily what can be called an economisation of time.

5. See for instance Elie Wiesel, The Stranger in the Bible (Cincinnati: Hebrew Union College, 1981); Stählin, G, 'Xenos.' In Theological Dictionary of the New Testament vol 5 (Grand Rapids: Eerdmans, 1967) 1-36; Koenig, J, New Testament Hospitality (Philadephia: Fortress Press, 1985); Christine D Pohl, Making Room: Recovering Hospitality as Christian Tradition (Grand Rapids: Eerdmans, 1999).

6. Volf, M, Exclusion and Embrace (Grand Rapids: Eerdmans, 1996), 29. 
Time for the other, time for reconciliation, time for hospitality seems to be an interruption of our optimally economic use of time. We find it difficult to take the pace of the other.

Thinking about the way certain views on time influence the moral life is certainly a complex matter, but a more moral and human public life asks that such an economised view of time be challenged.

Different people and different religious groups will find different resources to challenge such an economisation of time. For Christians the image of the Triune God as a God who is not timeless but became time so that we can have time, as well as practices like celebrating the church year and the Sunday, worship and leisure, can serve as important resources for such a challenge. ${ }^{7}$

We can argue that there are resources available that help us to imagine that we don't merely loose time through hospitality, but actually receive time through openness to the other and otherness. As Anne Dufourmantelle wrote in a reply to Jacques Derrida in a book on hospitality: "There is in Hebrew a similarity between making time and inviting/welcoming. It is as if language has the strange sort of intelligence that implies that you need at least two to produce or receive time." 8

An ethos of hospitality does not invite us to rethink only our view of time. It also requires a rethinking of spatial categories. Hospitality is not merely about taking the pace of the other, but also about finding or making space for the other. These two issues, of course, are tightly interwoven. ${ }^{9}$ The compression of our world due to globalisation makes the proximity of the other and otherness an increasing reality. In South Africa we are faced with the reality that the social spaces are not merely neutral spaces. No, in the same way that postmodern dialogue speak of contested knowledge, we can speak of contested space. These contested spaces serve as a battleground for the encounter with the stranger and his or her strangeness. Often this involves the quest for economic survival (we are reminded of the Romanian woman in Code Unknown who returns to Paris to find here place taken by other illegal immigrants.)

In an interesting article entitled "Race, Space and Civil Society" (in the book Sameness and Difference: Problems and Potentials in South African Civil Society), social psychologist Don Foster argues for the necessity to deal with the way in which spatial arrangements in our country have expressed racist configurations of place. For instance, the racial division between urban and rural, or "white" suburb and "black" township, often functions as a geographical concretisation of the distinction between the sphere of freedom and the sphere of subjugation and hence serves as a material and discursive barrier to the construction of civil society. He ends the article by writing: "If to transform racism is to change real spatial distributions and arrangements of bodies ... then the messy spaces of civil society should come to recognize that transforming racism - as boundaries between us

7. For a discussion of hospitality and time (with references), see my meditation Op soek na tyd: 'n etiek van gasvryheid deel 2 in Kruisgewys 1/ 2, November 2001, 4-8.

8. Derrida, J, Over gastvrijheid (Amsterdam: Boom, 1998), 121.

9. David Harvey uses in his highly instructive book The Condition of Postmodernity (Oxford: Blackwell, 1989) the concept of "time-space compression." He writes: "I use the word "compression' because a strong case can be made that the history of capitalism has been characterized by speed-up in the pace of life, while so overcoming spatial barriers that the world sometimes seem to collapse inwards upon us ... The experience of time-space compression is challenging, exciting, stressful, and sometimes deeply troubling, capable of sparking, therefore, a diversity of social, cultural, and political responses" (240). 
- will require going beyond changing hearts and minds, and also includes changing spaces." 10

Zygmunt Bauman also comments in his book Globalization: The Human Consequences that "an integral part of the globalizing processes is progressive spatial segregation, separation and exclusion ... A particular cause for worry is the progressive breakdown in communication between the increasing global and extra-territorial elites and the ever more 'localized' rest."'11

Remarks such as these of Foster and Bauman remind us that racial and economic injustices have everything to do with spaces. This reminds us not to treat "values" like hospitality as abstract and merely mental phenomena, but that they require spatialisation. We are painfully aware of the anti-hospitality of forced removals and the "cleansing" of spaces in the name of order or progress. Hospitality is not merely about finding time - it is also about making room. For Christians the vision of the space within the Triune life for the whole of creation can serve as motivation for "making room." 12

An adequate ethos of hospitality requires that we take the tyranny of time and the messiness of our social spaces seriously. Hence the need for hospitality as temporal and spatial embodiment.

\section{Hospitality and language}

In Code Unknown we see, as mentioned, the inability (and often the unwillingness) to communicate. Babel seems to reign. It is seemingly the experience of many people today, notwithstanding the immense progress with regard to our communication systems, that there is a growing inability to communicate.

It can be argued that in times of moral crisis it is especially important that we find the time and space for dialogue with the other in order to challenge racism, xenophobia, religious intolerance and loneliness. Or else we are left with the haunting vision of the total breakdown of communication at the end of Code Unknown - the vision of a child not merely unable to hear or speak, but having the experience of not being understood.

For some the willingness to be hospitable to the (moral) language(s) of others may lie in the memory of not merely the story of Babel, but also the story of Pentecost - about the miracle of people not merely able to speak in new ways, but actually hearing and understanding the other. The miracle of Pentecost is, as German theologian Michael Welker writes in his book God the Spirit, "not the fantastic and ominous characteristics of the Pentecost story - the "sound from heaven" and the divided tongues of fire - nor the "speaking in tongues" that initially invokes only incomprehension. The miracle of the baptism in the Spirit lies not in what is difficult to understand or incomprehensible, but in the totally unexpected comprehensibility and in an unbelievable, universal capacity to understand and act of understanding." 13

Other people may find other reasons not to give up on the conversations with others. Whatever their motivations, it is hard to image some sense of public morality without

10 Cochrane, J and Klein, B (eds.), Sameness and Difference: Problems and Potentials in South African Civil Society (Washington: The Council for Research in Values and Philosophy, 2000), 76.

11. Bauman, Z, Globalization: The Human Consequences (New York: Columbia University Press, 1998), 3.

12. J Moltmann writes for instance in his book The Trinity and the Kingdom (Minneapolis: Fortress Press, 1993), 109: "The Trinitarian fellowship of the Father and the Son and the Holy Spirit is so wide that the whole of creation can find space, time and freedom in it."

13. Welker, M, God the Spirit (Minneapolis: Fortress Press, 1994), 230,231. 
people who are willing to risk it with each other in compassion and hope through conversation and dialogue.

\section{Hospitality and structural and institutional concretisation}

The question can be asked whether hospitality is merely about inter-personal interactions. Hospitality has certainly to do with the face-to-face encounters between two persons or the dynamic interaction that takes place when a third enters. It will be a reduction, however, to limit hospitality to these I and Thou encounters (however important these encounters may be). To put it differently: an adequate ethos of hospitality requires structural and institutional concretisation.

The plea for hospitality is not merely a plea for an abstract value, but for people who embody hospitality concretely in time and space. Moreover, these embodiments are also not separated from institutions. We can describe the ethical intentions of hospitality, following Paul Ricoeur, "as aiming at the 'good life' with and for others in just institutions." 14

The challenges for more hospitable and just institutions and structures are probably some of the hardest challenges for an ethic of hospitality. In Code Unknown there is a scene where the farmer shoots his cows in frustration because of his powerlessness against global economic forces. Many people experience something of this powerlessness on a daily basis due to their encounter with cold and inhospitable structures, institutions or forces.

In his book Runaway World sociologist Anthony Giddens writes with regard to globalisation: "Many of us feel in the grip of forces over which we have no power. Can we reimpose our will on them? I believe we can. The powerlessness we experience is not the sign of personal failings, but reflects the incapacities of our institutions. We need to reconstruct those we have, or create new ones. For globalisation is not incidental to our lives today. It is the way we live now." 15

\section{Hospitality, lament and hope}

In a collection of essays of Jacques Derrida on religion (Acts of Religion), there is an interesting essay by Derrida titled Hostipitality. In this essay Derrida makes reference to hospitality as laughter (with reference to Gen 17 and 18), but also to hospitality as mourning, to hospitality as "weeping the welcome."

Maybe we need to recover more of hospitality as mourning. This implies the importance of lamenting over inhospitality. In various essays Denise Ackerman has argued for the importance of public lament for dealing with otherness and difference. ${ }^{17}$ Without public lament the haunting memories of inhospitality in our society will paralyse attempts to construct a more moral and human society.

But through these memories a restless hope can be born. In his speeches Russel Botman has often pointed to the need for social hope for the reconstruction of society. Without such hope or hopeful vision for the future we will not have the resources for hospitality and the will to embrace. But perhaps the way to grow in this hope is by taking the risk of hospitality.

14. Ricoeur, P, Oneself as Another (Chicago: University of Chicago Press, 1992), 172.

15. Giddens, A, Runaway World (New York: Routledge, 2000), 37.

16. Derrida, J, Acts of Religion. (New York: Routledge, 2002), 358.

17. For instance, "Lamenting Tragedy From 'The Other Side"" in Cochrane and Klein, Sameness and Difference, 213-241 and "On Hearing and Lamenting: Faith and Truth-Telling" in Botman, HR and Peterson, RM, To Remember and to Heal (Cape Town: Human and Rousseau, 1996), 47-56. 
In a world in which the code is unknown, hospitality can open our eyes to a strange code revealed. In the words of an old Celtic tune:

We saw a stranger yesterday.

We put food in the eating place.

Drink in the drinking place.

Music in the listening place.

And with the sacred name of the Triune God

He blessed our house.

Our cattle and our dear ones.

As the lark says in her song:

Often, often, often goes the Christ in the stranger's guise. ${ }^{18}$

18. Quoted by L Rasmussen in Moral Fragments and Moral Community (Minneapolis: Fortress Press, 1993), 155 . 